\title{
COIN USE IN AND AROUND MILITARY CAMPS ON THE LOWER-RHINE: NIJMEGEN - KOPS PLATEAU \\ By
}

JOS P.A. VAN DER VIN

\section{Introduction}

"The northern countries of Europe scarcely deserved the expense of labour and conquest. The forests and morasses of Germany were filled with a hardy race of barbarians, who despised life when it was separated from freedom; and though, on the first attack, they seemed to yield to the weight of the Roman power, they soon, by a signal act of despair, regained their independence, and reminded Augustus of the vicissitude of fortune". In these sentences the historian Edward Gibbon expressed his very negative opinion about the northwestern region of Europe ${ }^{1}$. The emperor Augustus, however, had quite different ideas about the same region. After protracted wars in Spain and in the Alpine regions in about 15 B.C. he decided to occupy permanently the area south and west of the Rhine and Meuse. Some years later, about 12 B.C., his stepson, the famous general Drusus, marched with several legions to the Rhine-estuary, near Katwijk, some miles west of Leiden. On the steep river bank, east of the later city of Nijmegen, a first, temporary camp of fortress size was erected, the first Roman settlement in the territory of the Netherlands (circa 15 B.C.). This fortification on the Hunerberg was built on the same spot where eighty years later the fortress (castra) of the tenth legion was to be constructed ${ }^{2}$. In addition, in the very early years of the Roman conquest, a more permanent military base was erected some hundred metres to the east of the Hunerberg, on the Kops Plateau, in the vicinity of the temporary camp (circa 12-10 B.C.).

Between 1986 and 1996 the National Archaeological Service of The Netherlands (R.O.B.) carried out large-scale excavations in the Kops Plateau area. Five successive military bases from the Augustan and Julio-Claudian periods have been the object of intensive research. Although the date of the foundation of the first base is not exactly known - it seems to have been about 12 B.C. in connection with Drusus' expedition - it is certain that the abandonment of the fifth and last base was the result of the Batavian Revolt

\footnotetext{
${ }^{1}$ E. Gibbon, Decline and Fall of the Roman Empire, chapter 1.

2 J.K. Haalebos, Castra und Canabae: Ausgrabungen auf dem Hunerberg in Nijmegen, 1987-1994 (Nijmegen 1995). Also J.K. Haalebos, Centuriae onder Centuriae Hof (Nijmegen 1998).
} 
of 69 A.D. ${ }^{3}$. An area of ca. 4-5 hectares is too small to house a complete legion; for this at least 20 hectares would have been necessary. Because many traces of cavalry equipment have been discovered, both inside and outside the base, it seems probable that during most of the first century Roman auxiliaries were encamped on the Kops Plateau. Perhaps it was built to house the famous Batavian horsemen, mentioned with respect in Roman literature. In the middle of the site a spacious and luxurious praetorium and the remains of many officers' houses were found; an exciting and important discovery. The size of the praetorium - about 2000 square metres - is equal to that of the large praetoria in the Roman castra along the Rhine in Germany. The excavators consequently supposed that this extraordinarily luxurious building found in the castellum on the Kops Plateau must have had a special purpose. At first it could have been the headquarters of Drusus during his campaigns along the Rhine; later on it was apparently the centre of a successive series of cavalry forts until the final destruction in 69 A.D. ${ }^{4}$

To give an idea of the enormous amount of finds made as a result of ten years of excavation, I shall only mention some of the most important categories. The archaeological material consists of more than 375,000 sherds of pots, amphorae and other ceramics; 35,000 fragments of stone; 30,000 bones and seeds, and thousands of metal objects.

As regards coin finds, about 4500 Roman and Celtic coins were discovered as strays in various places, both inside and outside the camp. In addition, 174 ancient Roman and Celtic coins were found in 6 small hoards of different size and origin: for instance a small pot with 86 silver denarii may be regarded as a savings hoard, a group of 19 small Celtic copper coins as an example of a lost purse ${ }^{5}$.

\section{The coin complex}

A coin complex of 4482 Roman and Celtic coins from a single Roman military site, the beginning and end of which are exactly dated (ca. 12 B.C. 69 A.D.), provides a unique opportunity to make important inferences about the beginning of the Roman occupation of The Netherlands, the process of romanization of the local German-Celtic population that started shortly after

${ }^{3}$ H. van Enckevort \& K. Zee, Het Kops plateau, Prehistorische grafheuvels en een Romeinse legerplaats in Nijmegen (Abcoude 1996), 31.

${ }^{4}$ Ibidem, 32-35.

${ }^{5}$ Publication of the coin hoards and the excavation complex in J.P.A. van der Vin, ed., 'Nijmegen, Kops Plateau', in FMRN III 1 (Berlin 2002). 
the occupation, and the introduction of Roman coin use in a Germanic society that was not yet accustomed to such a method of payment.

The coin list ${ }^{6}$ clearly shows that the Augustan period was the most important in the history of the site (Figure 1). Nearly $80 \%$ of the coins date from the Roman Republic and the age of Augustus (before 14 A.D.); most of them may be connected with the military operations in Germany under the command of Drusus (ca. 15-9 B.C.) and his brother Tiberius (from 8-7 B.C. onwards), the unfortunate Varus (i.e. the commander of the Roman army at the battle in the Teutoburgerwald, A.D. 9) and Germanicus (ca. A.D. 16). The later occupation period of this castellum, the years from the reign of Tiberius till the Civil War of 69 , is represented by another $10-15 \%$. But after the abandonment of the site in 69 a good many Flavian coins were lost on the site as well; the reason is that during this period the fortress (castra) of the 10th legion was situated on the Hunerberg in the vicinity of the Kops Plateau. Some roads undoubtedly led through the remains of the old castellum to the new fortress (castra), and travellers may have dropped some coins there. The coins may also have been lost or buried, however, in a small civilian settlement that had come into being outside the fortress. The impact of the existence of the fortress was undoubtedly very strong: in 104 the 10th legion was ordered to march to Aquincum (Budapest) and the coin list directly reflects its departure. From the time of Trajan 14 coins have been discovered. Only one is dated after 103, all other coins are of the earliest emissions of this emperor. After 103 perhaps all activity on the Kops Plateau area came to an end, for between 103 and 235 (Severus Alexander) only 8 coins were lost on this site. During the late 3rd century (after 270) or in the beginning of the 4th century under Constantine I there must have been a renewed occupation on a very limited scale; 45 coins of this period $(1 \%$ of the total amount) are an indication of some activity, either in a military or in a civilian context.

\section{The command of Drusus: occupation}

The temporary camp on the Hunerberg (about 15 B.C.) and the castellum on the Kops Plateau (from 12 B.C. onwards) are the earliest military settlements in the Dutch section of the Lower Rhine region. Therefore the coin finds of these sites can provide an idea of what coins the soldiers possessed upon their arrival in this area. In addition these coins can give an indication of the region from which the legions were moved to the Lower Rhine. We can have

\footnotetext{
${ }^{6}$ Van der Vin 2002, op cit. (n.5), passim.
} 
a fair impression of what the fortress (castra) on the Hunerberg was like (Figure 2). It existed during a short period (between ca. 15 and ca. 10 B.C.) and the site was only reoccupied after 69 A.D. by the fortress of the 10th legion. So the remains were not heavily mixed up and disturbed. The castellum on the Kops Plateau started very early as well, but in this case the coinage of the earliest phase has been mixed up with coins of later periods. In a recent study of the "Versorgung augusteischer Truppen mit Münzgeld", Johannes Heinrichs (University of Cologne) pointed out that in the earliest phase of the Roman occupation of the Lower Rhine region the coinage inside the fortresses and castella consisted mainly of silver and copper coins from Republican times and the transitional period between Republic and Empire ${ }^{7}$. In addition a limited number of early Augustan denarii and quinarii might be expected to be found, coins that had been minted in Rome, by Spanish mints (Emerita/Merida - Caesaraugusta/Zaragoza and Patricia/Cordoba) or at Lyon, where a production of aurei and denarii started about 15 B.C. Gold coins are very rare in these military settlements; they have only been found in greater quantities at the site of the battle of Varus at Kalkriese near Osnabrück ${ }^{8}$. A limited number of copper denominations was available. Copper asses with the head of Janus on the obverse had not been minted in Rome from about 80 B.C., but a small part of those important Republican emissions was still in circulation. In addition the large and heavy copper coins from Copia-Lyon and Vienna, struck by Octavian and Agrippa about 36 B.C. in the transitional period, were used in rather great quantities, either with the value of a dupondius ( $=2$ asses) or the value of an as ${ }^{9}$. Their weight is different from later Augustan copper asses, though. Because the standard coin of the Romans was the as and most of these coins found in the camps are halved, I prefer to call them dupondii; the halved coins could be used as asses. Predominant in these military settlements, however, is the great number of copper coins from Nemausus. At this place Augustus organized a relatively large-scale production of such coins. The originally local mint of Nemausus /Nîmes produced large amounts of copper coins bearing the heads of Augustus and Agrippa on the obverse and a crocodile chained to a palmtree on the reverse. The production started, according to a recently revised

\footnotetext{
7 J. Heinrichs, 'Überlegungen zur Versorgung augusteischer Truppen mit Münzgeld', in: Politics, administration and society in the Hellenistic and Roman world. Proceedings of the International Colloquium, Bertinoro 19-24 July 1997 (Leuven 2000), 155-214.

${ }^{8}$ Heinrichs 2000, op.cit. (n.7), 163-164.

9 A. Burnett, et al., eds., The Roman Provincial Coinage I (London 1996), nrs. 514, 515 (Copia) and 517 (Vienna).
} 
dating, in 16 B.C. and was continued till 7 B.C. on an enormous scale ${ }^{10}$. Many millions of coins must have been struck in the local mint of Nemausus, in auxiliary mints in the same town and perhaps also in mobile, travelling mints near the location of the legions. The main aim of this production was the supply of the Roman army with copper coins, both in Raetia (Switzerland) and on the Lower Rhine. In Nijmegen - Kops Plateau 699 pieces have been discovered, either genuine coins from Nemausus, or local imitations of the type. In the other early fortresses along the Rhine we also find many hundreds of these coins. After 7 B.C. the coin production at Nemausus was transferred to the mint of Lyon, where the striking of gold and silver was temporarily replaced by a quantitatively important production of asses showing the altar of Roma and Augustus situated at Lyon ${ }^{11}$. Between 7 and 3 B.C. an enormous amount of coins of this Lyon-I type was struck, particularly for the legions on the Rhine, so that after 7 B.C. for many years the circulation in the camps was dominated completely by this coin type alone (Figure 3). That the date of transition was about 7 B.C. is proved by the coin finds of the fortress in Oberaden on the Lippe. This was a bridgehead of the Roman army in Germanic territory, built in 12-11 B.C. After a few years, during the winter of 8-7 B.C., as dendrochronological data indicate $^{12}$, the fortress was abandoned. Coins struck at Nemausus dominate almost exclusively the finds in Oberaden, and the altar series of Lyon is still lacking at this early site, because the production of this type started later in 7 B.C., some months after Oberaden had been abandoned.

After comparing the coin lists of the military sites at Neuss, Oberaden on the Lippe, Vetera-I (Xanthen) and Nijmegen-Kops Plateau, Heinrichs points out that the coin list of Neuss presents a different pattern from the others $^{13}$. At Neuss local copper coins from the originally Celtiberian and Iberian, romanized cities in the Ebro valley are completely lacking; more coins here come from Rome or northern Italy. He consequently suggests that the Neuss camp was a little bit earlier than the other military settlements - an idea supported by terra sigillata sherds - and that the soldiers encamped there came directly from Italy. I think his suggestion is correct, for at the

\footnotetext{
${ }^{10}$ Heinrichs 2000, op.cit. (n.7), 171-173. In The Roman Imperial coinage (RIC) I (2nd edition from 1984 ) this series is still dated as: circa 20-10 B.C.

$11 \mathrm{~J}$. van Heesch, 'Proposition d'une nouvelle datation des monnaies en bronze à l'autel de Lyon frappées sous Auguste', in Bulletin de la Société Française de Numismatique 48 (1993), 535-538.

${ }^{12}$ Heinrichs 2000, op.cit. (n.7), 183-184; J.S. Külborn, 'Das Römerlager Oberaden', in J.S. Kühlborn, ed., Germaniam pacavi. Archäologische Stätten augusteischer Okkupation (Münster 1995), 103-124.

${ }^{13}$ Heinrichs 2000, op.cit. (n.7), 184-187.
} 
other three sites we find a fair amount of local Spanish coins from cities like Bilbilis, Turiaso, Calagurris, Lepida-Celsa or Caesaraugusta, all situated in the Ebro valley in north-eastern Spain ${ }^{14}$. They are a clear indication that after the Cantabrian wars, which had been fought during the twenties B.C., Roman troops were withdrawn from north-western Spain and, marching through southern Gaul, where they picked up the dupondii of Vienna and Copia, which were circulating in great numbers in that area, they arrived on the Lower Rhine in order to settle the diffuse political situation in northeastern Gaul according to the new strategy of the emperor.

The castellum on the Kops Plateau is at the most five years later than the temporary base on the Hunerberg. Although coin finds there differ greatly in quantity, I think the different proportions between the dupondii of Vienna and Copia are not completely fortuitous. At the Hunerberg site coins from Copia ( 2 complete and 5 halves) and Divus Iulius ( 3 halves) are much more frequent than coins from the Vienna mint (only 2 halves). In the Kops Plateau castellum the numbers are completely different: Divus Iulius: 1 coin, Copia 5 coins ( 2 complete and 3 halves) and Vienna 80 coins of which 73 pieces were halved. It is clear that during these years the composition of the coinage was constantly changing and that the circulation time of quite a few emissions was not very long. Wear and tear, hoarding and loss created a considerable reduction of the coinage available for the soldiers in the camps; a frequent influx of new-minted coins - primarily from Nemausus - to keep the total quantity of coin at least at the same level, was necessary in order to prevent unrest and mutiny. At first the production of Nemausus was large enough to keep up the economic activities in the camps. Later, however, the expanding economy, combined with an increasing use of Roman coins by local residents outside the camps, caused a serious logistical problem which Roman authorities had to solve. The mint of Nemausus, the auxiliary mints and local mints included, could not supply the growing demand for coins any more. For that reason the production of the Lyon mint was changed from the striking of gold and silver coins to the most voluminous copper coinage Rome ever produced. The altar-I series started about 7 B.C. and during at least five years many millions of these coins were transported mainly to the Lower Rhine region.

\section{The command of Tiberius: monetization of Germania Inferior}

\footnotetext{
${ }^{14}$ See Van der Vin 2002, op.cit. (n.5), nrs. 3140-3162 for the Spanish coins in Nijmegen. Further, Heinrichs 2000, op.cit. (n.7), note 73.
} 
The coin list of Nijmegen - Kops Plateau presents a total of 1130 coins from Lyon (25\% of the total amount!). Of this number 704 pieces can be attributed with certainty to the first altar-series, 145 coins to the later, second altar-series, struck with slightly revised types by Augustus and Tiberius Caesar between 9 and 14 A.D., and 281 pieces are heavily worn and cannot be attributed with certainty to the first or second emission, but - looking at the proportions between the two series - most of them should be considered as altar-I pieces as well. Not only the number of the Lyon coins is much larger than the Nemausus issues, but there is a more important difference between these two Roman standard coins for the troops on the Rhine border. The Nemausus issues are usually found inside the camps, the Lyon altar series can be found either inside or outside them. In the coin finds from the provinces of Gelderland and Brabant issues of Nemausus are relatively scarce; in other provinces of the Netherlands they are very rare or even completely missing. In Gelderland only 15 coins of Nemausus have been found outside Nijmegen; most of them come from Rossum or the Betuwe region. The number of Lyon coins, however, in the same province is 30 pieces, all of them found outside Nijmegen in a great number of places round that city. In Brabant only 6 coins of Nemausus have been reported, most of them coming from the river area; the number of Lyon coins is 26 pieces, partly found in Cuijk, partly on various sites in the river area as well ${ }^{15}$. I think that this different proportion between the coins of Nemausus and Lyon reflects the change that Tiberius made at the time he took over the command on the Rhine. Heinrichs' thesis is that Tiberius realized that the Roman presence on the Rhine would not be of short duration and that, for that reason, he changed the Roman economic policy and started a process of forced romanization of the local German population. This thesis finds confirmation in the coin finds of the region around Nijmegen ${ }^{16}$. The Nemausus issues were primarily of a military and Roman character; they were mainly used inside the camp, in the marketplace before the gates and, of course, by way of trade and traffic, eventually they could spread over the countryside. The Lyon series, however, was issued, not only for military use inside the camps, but for civilian use by the local population as well. These coins are also found in western-Brabant, far away from the military sphere of the castellum in Nijmegen.

${ }^{15}$ Coin finds in the Netherlands: Archives of the National Museum of Coins and Medals (Rijksmuseum Het Koninklijk Penningkabinet), Leiden.

${ }^{16}$ Heinrichs 2000, op.cit. (n.7), caput VI: 'Neue Kleingeldserien als Indikatoren eines konzeptionellen Wandels in Germanienkrieg', 187-195. 
A second argument in favour of a change in the economic policy is the large-scale creation of small change, that also started about the year 7 B.C. ${ }^{17}$. With the production of the smallest denomination of the Roman coin series, the quadrans or quarter of an as, it became possible to pay not only for very expensive acquisitions, but also for small everyday purchases. It is interesting to observe how Tiberius delegated the production of this small change mainly to the local population. In Lyon a small production of Roman quadrantes had started after 15 B.C., but only a small part of these coins found its way to the Rhine. Most of the coins of the smallest denomination in the camp on the Kops Plateau are Celtic copper coins of the AVAVCIAtype. This local Celtic-Germanic coinage started after 7 B.C. in the region between Rhine and Meuse. Large amounts of coins were minted, in largescale production, and many hundreds of these small copper coins, in most cases of bad quality, have been found in the Augustan military bases. In Nijmegen about 550 pieces have been discovered during the excavations, all dating from the period between 7 B.C. and A.D. 14. The presence of so many low value coins both inside the camp and before its gates, outside the Kops Plateau castellum, is an indication of many everyday commercial activities, in which small change played an important role. In the LowerRhine area, during the later Augustan period, it was possible to pay not only with high value coins of gold and silver, especially for luxurious imports, but also with a number of small copper denominations for daily expenses.

\section{Trade contacts within the Empire}

Pottery fragments, in particular, are evidence for intensive trade relations between the castellum on the Kops Plateau and many regions of the Roman empire, both distant and nearby ${ }^{18}$. It is certain that for the commander and his officers luxurious food was available in the camp; as far as possible the same dishes were served at their table as in Mediterranean regions. Dates were imported from Libya, wines from Greece, Italy, Spain and southern Gaul. Garum, the famous fish sauce which in antiquity made every dish palatable, was imported from southern Spain or the Costa Brava region. Olive oil was transported from Spain and central Italy. Cattle, on the other hand, were raised in the vicinity and grain for the daily bread ration was also cultivated nearby. However, small and valuable objects could be imported

\footnotetext{
${ }^{17}$ Heinrichs 2000, op.cit. (n.7), 187-190.

${ }^{18}$ Van Enckevort and Zee 1996, op.cit. (n. 3), 'Wat aten de militairen?', 48-53 and illustrations on p. 49.
} 
from far away regions. The Roman road system and the intensive Mediterranean shipping facilitated transport of luxury goods over great distances.

During the excavations there was a curious discovery: a preserving-jar containing the breasts of about 30 thrushes, imported from the Ardennes forest region. On opening the contents had turned out to be tainted and therefore the pot with its contents was thrown away into a pit. The same happened with a pot of tainted Spanish mackerels, discovered in a ditch. All these remains of pottery - either with or without their contents - can now provide us with an idea about trade relations of a first-century military Roman settlement in a frontier region in the north-western part of the Roman empire, far away from the Mediterranean. The Romans tried to maintain their life-style as far as possible, and, judging from the material found in their camp, we may conclude that they were rather successful in their attempts.

\section{Conclusion}

The coin finds inside and outside the camps show that the reorganisation of the economy and the introduction of a coin system with local as well as Roman coins, were both successful. The profit for the Romans was great: they could purchase food, grain and meat, at reasonable prices in the vicinity of their camps. Long distance transport of large quantities of the grain and meat, which the Romans needed every day would have cost too much and would also have created insurmountable logistical problems. For the Germanic population it was also attractive to buy Roman products with the Roman coins they had earned at the markets round the fortresses: glass, terra sigillata and luxury products provided by the Roman merchants of the longdistance trade. In that way a process of mutual understanding and romanization of the local population started; it would take a long time before the integration was completed and a new civilisation built up in the Lower Rhine area. Tiberius apparently realized that in order to monetize the economy of the countryside in a short period, an expensive operation was the only way to create stability in this swampy and forested region. He undertook this large-scale operation and was in the end successful. The coins of the Kops Plateau are a testimony to his activities in the Lower Rhine region.

Leiden, March 2002 
Figure 1

NIJMEGEN KOPS PLATEAU

excavations 1986-1996

Republic $\quad 309$

$6,89 \%$

Augustus

2356

$52,56 \%$

(Celt)Iberic / Roman Spain

23

Celtic (including AVAVCIA-type) $\quad 618$

$0,51 \%$

Late 1st c. B.C. / 1st c. A.D.

469

$13,79 \%$

$10,46 \%$

\begin{tabular}{lrr}
\hline Tiberius & 106 & $2,37 \%$ \\
Caligula & 150 & $3,35 \%$ \\
Claudius I & 192 & $4,28 \%$ \\
Nero & 29 & $0,65 \%$ \\
Varia (before 69) & 3 & $0,07 \%$ \\
\hdashline Civil War & 3 & $0,07 \%$ \\
Flavian period & 67 & $1,49 \%$ \\
Nerva - Severus Alexander & 25 & $0,56 \%$ \\
Late 3rd century (from 270 A.D.) & 14 & $0,31 \%$ \\
4th century & 31 & $0,69 \%$ \\
& & \\
unknown Roman coin & 87 & $1,94 \%$ \\
& &
\end{tabular}


Figure 2

\section{NIJMEGEN}

Augustan castra on the Hunerberg

ca. 15-12 B.C.

Silver Bronze

Celtic

213

Roman Republic

$4 \quad 7 / 2$

Transitional period

$7 \quad 2+16 / 2$

(44-27 B.C.)
a. Divus Julius
$3 / 2$
b. Vienna
$2 / 2$
c. Copia
$2+5 / 2$
d. other coins
$6 / 2$

Augustus

$2+4 / 2$

Nemausus - I

$2+2 / 2$

Nemausus - I/II

$1 / 2$

Lyon - I (doubtful / later intrusion?)

$1 / 2(?)$

Vespasianus (later intrusion)

1

13 Silver coins

$\overline{18}+27 / 2$ Bronzes

This figure after Haalebos, Castra und Canabae (see note 2).

$[2 / 2=2$ halved coins $]$ 
FIGURE 3

AUGUSTAN - TIBERIAN CASTELLA

in The Netherlands (Rhine-region) / Germany (Lippe-region)

Nemausus Rome Lyon-I Lyon-I/II Lyon-II

Oberaden $\quad 99 \% \quad 1 \%$

ca. 11-9 B.C.

$\begin{array}{llllll}\text { Kops Plateau } & 31 \% & 16 \% & 32 \% & 13 \% & 8 \%\end{array}$

ca. 10 B.C.

Haltern $\quad 7,5 \% \quad 12,5 \% \quad 80 \%$

ca. 9 B.C.

$\begin{array}{llllll}\text { Vechten } & 3,5 \% & 31 \% & 32,5 \% & 13 \% & 21 \%\end{array}$

ca. 5 A.D.

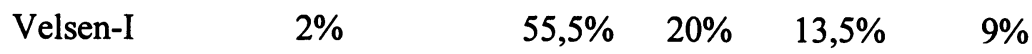

ca. 14-16 A.D. 